\title{
IMPLEMENTASI PEMBELAJARAN AL-QUR'AN METODE LITTAQWA DI SDIT NUR HIDAYAH SURAKARTA DAN METODE KARIMAH DI MI NURUL KARIM KARANGANYAR TAHUN AJARAN 2019/2020
}

\author{
${ }^{1}$ Bayu Mufti Sugiyanto, ${ }^{2}$ Ari Anshori, ${ }^{3 *}$ Muthoifin \\ 1,2,3 Magister Penidikan Agama Islam Sekolah Pascasarjana \\ Universitas Muhammadiyah Surakarta \\ E-Mail: bayumuftisugiyanto@gmail.com¹, aa112@ums.ac.id², mut122@ums.ac.id*
}

\begin{abstract}
This research aims to describe the implementation of the Littaqwa method in learning the Qur'an at SDIT Nur Hidayah Surakarta and the karimah method at MI Nurul Karim Karanganyar and describe the supporting and inhibiting factors. This type of research is field research, with a qualitative approach. The object of research is SDIT Nur Hidayah Surakarta and MI Nurul Karim Karanganyar. Research subjects include the Principal / Madrasa, al-Qur'an learning coordinator, teachers who teach the al-Qur'an and several students. Data collection techniques are done by observation, interview and documentation. Data analysis was performed descriptively qualitative. The results showed that the main target of learning the Koran at SDIT Nur Hidayah was an understanding of the principles of recitation with the target of memorization of at least 2 juz (juz 29 and 30) and memorization of hadith, the learning method used was littaqwa by applying three learning models namely classical with the teacher, independent classical and oneon-one classics. Evaluations are conducted at the end of each meeting and evaluation of volume increases. While in MI Nurul Karim the target of memorization is owned by \pm 5 juz graduates (juz 26, 27, 28, 29 and 30), learning using the karma method which has four teaching principles namely talqin, tikrar, tahqiq and tabyin. Evaluation of learning is done in 3 stages, namely the class exam, juziyyah and the peak is the best tahfidz school overall champion test. The implementation of al-qu'an learning has implemented a constructivism approach in choosing learning strategies, as an effort to create a learning process that is appropriate to the character of students. Supporting factors that encourage the implementation of the learning of the Qur'an include the standardization of qualified educators and workshops specifically Tahfidz teachers, innovation and strategies in delivering learning, using teaching aids and student handbooks that are easily understood, having Iad classes specifically for 1 grade of elementary school, has its own distinctive tone or hum. While the obstacles faced include students who are not fluent in reading the Koran, lack of guidance and support from families for children, and there are still children who lack concentration and attention when the learning process takes place.
\end{abstract}

Keyword: method, al-Qur'an learning, litaqqwa, karimah

Abstrak: Penelitian ini bertujuan untuk medeskripsikan implementasi metode littaqwa dalam pembelajaran al-Qur'an di SDIT Nur Hidayah Surakarta dan metode karimah di MI Nurul Karim Karanganyar serta mendeskripsikan faktor pendukung dan penghambatnya. Jenis penelitian yang digunakan adalah field research, dengan pendekatan kualitatif. Objek penelitian adalah SDIT Nur Hidayah Surakarta dan MI Nurul Karim Karanganyar. Subjek penelitian diantaranya yaitu Kepala Sekolah/ Madrasah, koordinator pembelajaran al-Qur'an, para guru yang mengajar pelajaran al-Qur'an dan beberapa siswa. Teknik 
pengumpulan data dilakukan dengan observasi, wawancara dan dokumentasi. Analisis data dilakukan secara deskriptif kualitatif. Hasil penelitian menunjukkan bahwa target utama pembelajaran al-Qur'an di SDIT Nur Hidayah adalah pemahaman tentang kaidah ilmu tajwid dengan target hafalan minimal 2 juz (juz 29 dan 30) dan hafalan hadits, metode pembelajaran yang digunakan adalah littaqwa dengan menerapkan tiga model pembelajaran yaitu klasikal bersama guru, klasikal mandiri dan klasikal satu-satu. Evaluasi dilakukan setiap akhir pertemuan dan evaluasi kenaikan jilid. Sedangkan di MI Nurul Karim target hafalan yang dimiliki oleh lulusannya \pm 5 juz (juz 26, 27, 28, 29 dan 30), pembelajaran menggunakan metode karimah yang mempunyai empat prinsip pengajaran yaitu talqin, tikrar, tahqiq dan tabyin. Evaluasi pembelajaran dilakukan dengan 3 tahap yaitu ujian kelas, juziyyah dan puncaknya adalah ujian juara umum terbaik tahfidz sekolah. Implemetasi pembelajaran al-qu'an telah menerapkan pendekatan kontruktivisme dalam memilih strategi pembelajaran, sebagai upaya menciptakan proses pembelajaran yang sesuai dengan karakter peserta didik. Faktor pengdukung yang mendorong implementasi pembelajaran al-Qur'an meliputi standarsasi pendidik yang mumpuni dan workshop terkhusus guru tahfidz, inovasi dan strategi dalam penyampain pembelajaran, menggunakan alat peraga dan buku pegangan siswa yang mudah dipahami, memiliki kelas I'dad terkhusus untuk kelas 1 SD, memiliki nada atau senandung khas tersendiri. Sedangkan kendala yang dihadapi antara lain masih terdapat peserta didik yang belum lancar membaca al-Qur'an, kurangnya bimbingan dan support dari keluarga terhadap anak, dan masih terdapat anak yang kurang konsentrasi dan perhatian ketika proses pembelajaran berlangsung.

Kata Kunci: metode, pembelajaran al-Qur'an, litaqqwa, karimah.

\section{PENDAHULUAN}

Al-Qur'an adalah perkataan (firman) Allah yang mengandung kemukjizatan, diturunkan kepada Nabi Muhammad SAW yang ditulis dalam mushaf melalui perantaraan malaikat Jibril a.s. selama kurang lebih dua puluh tiga tahun yang diriwayatkan secara mutawatir, yang membaca bernnilai ibadah. Selain itu, diperintahkan-Nya untuk dibaca ketika shalat serta adanya perintah untuk membacanya sebagai bentuk ibadah tersendiri, yaitu ibadah tilawah. ${ }^{1}$ Kitab suci Al-Qur'an memiliki kekuatan yang luar biasa yang berbeda di luar kemapuan seluruh makhluk-Nya. Sebagaimana yang disebutkan dalam al-Qur'an:

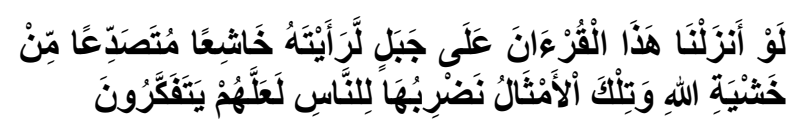

1 Salafuddin AS., Ngaji Metal Metode Talqin, (Jakarta: Wali Pustaka, 2018), h. 14-15
"Sekiranya Kami turunkan Al-Qur'an ini kepada sebuah gunung, pasti kamu akan melihatnya tunduk terpecah belah disebabkan takut kepada Allah." (QS. Al-Hasyr: 21).

Al-Qur'an sebagai landasan kehidupan manusia adalah mukjizat yang abadi, ia akan berlaku sepanjang zaman dimana semakin maju ilmu pengetahuan maka semakin terlihat juga validitas kemukjizatannya. Menjadi suatu keharusan yang tidak dapat dielakkan lagi untuk mempelajari dan mengajarkan al-Qur'an, karena al-Qur'an adalah pedoman agama Islam yang asasi dan hakiki. Al-Qur'an merupakan sumber asal manusia dalam pembinaan untuk kepribadian yang islami. ${ }^{2}$

Sebagaimana disebutkan dalam hadits:

2 Arham bin Ahmad Yasin Al-Hafidz, Agar Sehafal AlFatihah, (Bogor: CV Hilal Media Group, 2013), h. 11 


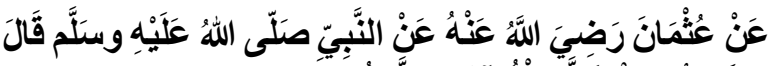

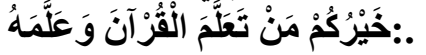

"Sebaik-baik kalian adalah orang yang belajar Al-Qur'an dan mengamalkan / mengajarkannya." (HR. Bukhari dan Tirmidzi). ${ }^{3}$

Mengingat demikian pentingnya peranan al-Qur'an dalam kehidupan manusia maka kemampuan membaca alQur'an yang baik dan benar (fasih) juga merupakan bagian terpenting dalam pendidikan Islam. ${ }^{4}$ Oleh karena itu, salah satu tolak ukur yang bisa digunakan untuk menilai kesadaran masyarakat dalam mempelajari dan mengamalkan ajaran-ajaran Islam serta menilai kondisi pendidikan Islam adalah kemampuan anak-anak dalam membaca al-Qur'an. ${ }^{5}$ Pembelajaran al-Qur'an adalah salah satu bentuk dari kepedulian hamba Allah dalam mempelajari kitab-Nya. Dalam pelaksanaannya dibutuhkan perhatian yang besar pada metode pembelajaran al-Qur'an dan efektifitas dan efisiensinya, hal ini bertujuan agar hasil dapat dicapai dengan maksimal. Metode pembelajaran al-Qur'an yang telah ditemukan oleh para pakar dalam pembelajarn al-Qur'an sudah sangat banyak, maka hendaknya pelaksanaan pembelajaran al-Qur'an mengikuti memperhatikan teori yang sudah ada. ${ }^{6}$ Maka saat ini banyak lembaga-lembaga atau sekolah-sekolah yang berlomba-lomba untuk memberikan dan meningkatkan jaminan kualiatas lulusan yang berkompoten terutama

3 Shahih Al-Bukhari/ Kitab Fadha'il Al-qur'an/Bab Khairukum Man Ta'allama Al-qur'an Wa 'Allamah/ Hadits No 5027.

4 Muthoifin, Mengungkap Isi Pendidikan Islam Perspektif Al-Qur'an Surat Al-Ashr Ayat 1-3, Proseding the 7th University Research Colloqium 2018 STIKES PKU Muhammadiyah Surakarta, 2018.

5 Zakiyah Derajar, Ilmu Pendidikan Islam, (Jakarta:Bumi Aksara, 1996), h. 134

6 Muthoifin, Ari Anshori dan Suryono. Metode Pembelajaran Tahfiz Al-Qur'an Di Madrasah Aliyah Tahfiz Nurul Iman Karanganyar Dan Madrasah Aliyah Al-Kahfi Surakarta. Profetika Jurnal Studi Islam, Vol. 17, No 02, Desember 2016, h. 32. dalam kemampuan membaca al-Qur'an dengan baik dan benar.

Dalam hal ini, pengelola lembaga akan membutuhkan sebuah metode yang dapat menunjang tercapainya tujuan dari lembaga tersebut. Sebagaimana pembelajaran lainnya, maka pembelajaran Al-qur'an juga memerlukan pengembangan konten, mutu dan konteks maupun support yang mampu meningkatkan dan memberikan jaminan kepada setiap lulusan bahwa mereka dipastikan bisa dan mampu membaca alQur'an dengan baik dan benar. Saat ini sudah mulai muncul dan berkembang macam-macam metode pembelajaran al-Qur'an, diantaranya metode Littaqwa yang dibuat oleh Tim Qur'an Center Yayasan Nur Hidayah Surakarta dan merode Karimah yang dibuat oleh Yayasan Nurul Karim Karangayar. Kedua metode ini masing-masing memiliki ciri khas dan keunggulan. Oleh karena itu peneliti tertarik untuk meneliti tentang "Implementasi Pembelajaran al-Qur'an Metode Littaqwa di SDIT Nur Hidayah dan Metode Karimah di MI Nurul Karim."

Rumusan masalah pada penelitia ini adalah: 1) Bagaimana implementasi metode Littaqwa dalam proses pembelajaran al-Qur'an di SDIT Nur Hidayah Surakarta dan metode Karimah di MI Nurul Karim Karanganyar tahun ajaran 2019/2020? 2) Apa saja faktor pendukung dan penghambat implemetasi metode Littaqwa di SDIT Nur Hidayah Surakarta dan metode Karimah di MI Nurul Karim Karanganyar tahun ajaran 2019/2020?

Tujuan dari penelitian ini yaitu medeskripsikan implementasi serta faktor pendukung dan penghambat metode Littaqwa dalam proses pembelajaran alQur'an di SDIT Nur Hidayah Surakarta dan implementasi metode Karimah di MI Nurul Karim Karanganyar tahun ajaran 2019/2020. 


\section{METODE PENELITIAN}

Jenispenelitianyangdigunakandalam penelitian ini adalah penelitian lapangan (field research), dengan pendekatan kualitatifyang prosedurnya menghasilkan data deskriptif. Objek penelitian adalah tempat dilakukannya penelitian, misalnya di sekolah, msyarakat, dan lembaga yang diteliti. ${ }^{7}$ Objek penelitian adalah SDIT Nur Hidayah Surakarta dan MI Nurul Karim Karanganyar. Subjek penelitian diantaranya yaitu Kepala Sekolah/ Madrasah, koordinator pembelajaran al-Qur'an, para guru yang mengajar pelajaran al-Qur'an dan beberapa siswa. Teknik pengumpulan data dilakukan dengan observasi secara langsung yaitu cara pengambilan data dengan menggunakan mata tanpa ada pertolongan alat standar lain untuk keperluan tersebut, ${ }^{8}$ wawancara dan dokumentasi. Analisis data dilakukan secara deskriptif kualitatif yang terdiri dari tiga tahapan yaitu reduksi data, display data dan mengambil kesimpulan dan verifikasi. ${ }^{9}$

\section{HASIL DAN PEMBAHASAN}

Implementasi Pembelajaran Al-Qur'an di SDIT Nur Hidayah

SDIT Nur Hidayah mempunyai target lulusan minimal memiliki hafalan dua juz

7 Sudarno Shobron, dkk, Pedoman Penulisan Tesis, (Surakarta: Program Pascasarjana Universitas Muhammadiyah Surakarta, 2016), h. 18

8 Moh. Nazir, Metode Penelitian, (Bogor: Ghalia Indonesia, 2013), h. 154

9 Kaelan. Metode Penelitian Kualitatif Interdisipliner. (Yogyakarta: Paradigma, 2012) hlm. 132. yaitu juz 29 dan juz 30. Pembelajaran alQur'an dilaksanakan setiap hari dengan durasi waktu yang berbeda-beda pada setiap kelasnya, waktu kegiatan belajar mengajar (KBM) dibagi menjadi tiga yaitu KBM 60 menit, KMB 70 menit dan KBM 90 menit.

Metode pembelajaran al-Qur'an yang digunakan di SDIT Nur Hidayah adalah metode littaqwa. Littaqwa adalah metode pembelajaran al-Qur'an yang disusun oleh Tim Qur'an Center Yayasan Nur Hidayah Surakarta, merupakan sebuah metode yang dirancang dalam rangka untuk memudahkan guru dan siswa dalam belajar membaca al-Qur'an dan belajar menulis al-Qur'an sehingga mereka bersemangat dalam berinteraksi dengan al-Qur'an dan mencintai al-Qur'an. Metode littaqwa menggunakan tiga model pembelajaran yaitu klasikal bersama guru yaitu guru membimbing bacaan murid dengan jalan guru dan murid membaca secara bersama-sama bacaan yang sudah dicontohkan oleh guru, klasikal mandiri yaitu murid membaca bersama-sama bacaan yang sudah dicontohkan oleh guru tanpa dibersamai oleh guru, tetapi guru tetap mengontrol bacaan murid, dan klasikal satu-satu yaitu murid diminta oleh guru untuk membaca dan muridmurid yang lain menyimak dengan seksama. Pada metode littaqwa terdapat 5 buku yaitu buku jilid I'dad, jilid 1, jilid 2, jilid 3, dan jilid 4 (Tajwid, Gharib), setiap buku mempunyai pokok bahasan dan cara pengajaran yang berbeda-beda. 
Tabel Target Pembelajaran SDIT Nur Hidayah Surakarta

\begin{tabular}{|c|c|c|c|c|c|c|}
\hline KELAS & SMT & TGK & PROGRAM & HAL & $\begin{array}{l}\text { JML } \\
\text { HAL }\end{array}$ & TM \\
\hline \multicolumn{6}{|c|}{ MASA TA'ARUF Littaqwa } & 3 \\
\hline \multirow{4}{*}{1} & \multirow[t]{2}{*}{1} & 1 & Littaqwa Jilid 1 & $1-31$ & 31 & 62 \\
\hline & & 2 & Littaqwa Jilid 2 & $1-15$ & 15 & 30 \\
\hline & \multirow{2}{*}{2} & 2 & Littaqwa Jilid 2 & $16-26$ & 11 & 22 \\
\hline & & 3 & Littaqwa Jilid 3 & $1-26$ & 26 & 67 \\
\hline \multirow{4}{*}{2} & \multirow{2}{*}{1} & 4 & Tartil (Juz 1) & $2-21$ & 20 & 40 \\
\hline & & 4 & Tartil (Juz 2) & $22-41$ & 20 & 50 \\
\hline & \multirow{2}{*}{2} & 4 & Tartil (Juz 3) & $42-61$ & 20 & 40 \\
\hline & & 5 & Littaqwa Jilid 4 & $1-22$ & 22 & 45 \\
\hline \multirow{5}{*}{3} & \multirow{2}{*}{1} & 5 & Littaqwa Jilid 4 & $23-29$ & 7 & 14 \\
\hline & & 6 & Munaqosyah & & & 15 \\
\hline & \multirow{3}{*}{2} & 7 & Tahfidz/Ziyadah & & & 61 \\
\hline & & 7 & Tahfidz/Ziyadah & & & \\
\hline & & 7 & Tahfidz/Ziyadah & & & \\
\hline
\end{tabular}

Asumsi Standar : 1 halaman Littaqwa $=2 \mathrm{x}$ Tatap Muka

Evaluasi pembelajaran dilakukan dengan macam yaitu evaluasi harian/ setiap akhir pertemuan dan evaluasi kenaikan jilid. Seorang murid harus melalui tahapan-tahapan di setiap tingkatan jilidnya dengan standar yang telah ditentukan. Jika murid belum lancar dan fasih dalam membaca tamrinat, maka harus mengulangi di bagian yang masih kurang menguasai. Murid dinyatakan lulus dan diperbolehkan melanjutkan ke tingkat/ jilid berikutnya jika benar-benar menguasai materinya, lancar dan tidak salah dalam membacanya, termasuk hafal semua atau sebagian hadits-hadits pilihannya. Pengujian kenaikan tingkat/ jilid dilakukan dengan membaca acak setiap halaman tamrinaat (latihan) dari materi awal sampai materi akhir di setiap jilid yang diuji, materi ujian langsung dari Koordinator Al-Qur'an dan pengujian jilid dilakukan oleh seorang Koordinator AlQur'an atau guru Al-Qur'an yang sudah ditunjuk.
Implementasi Pembelajaran Al-Qur'an di MI Nurul Karim

MI Nurul Karim mempunyai beberapa program unggulan salah satunya adalah pembelajaran al-Qur'an yang berfokus pada tahfidz al-Qur'an dengan tujuan mencetak anak didik yang akrab dengan al-Qur'an yang mampu membaca dan menghafal Al-Quran secara mutqin dan bertajwid. Target hafalan yang dimiliki oleh lulusannya adalah \pm 5 juz.

Pembelajaran al-Qur'an di MI Nurul Karim menggunakan metode Karimah. Dengan 4 prinsip pengajaran yaitu Talqin (mentalqinkan bacaan Al-Quran), Tikrar (mengulang-ulang bacaan yang ditalqin hingga jelas dan mampu diterima oleh peserta didik), Tahqiq (membaca dengan tempo bacaan tahqiq (jelas) pada saat mentalqinkan bacaan kepada peserta didik) dan Tabyin (menjelaskan secara singkat kesalahan pada saat terjadi kesalahan tajwid). 
Dalam proses pembelajaran al- 90 menit setiap harinya, jam 08.00 WIBQur'an di MI Nurul Karim peserta didik 09.30 WIB. Terbagi menjadi tiga sesi yaitu dibagi menjadi 4 level atau kelas yaitu 30 menit (muqadimah, muroja'ah klasikal, kelas tamhidi, kelas talaqqi, kelas tahfidz talqin klasikal), 30 menit menghafalkan, 30 awal, dan kelas tahfidz tsany. Program menit setoran pribadi, dengan ketentuan pembelajaran al-Qur'an dimulai dari hari waktu yang berbeda-beda berdasarkan Senin sampai dengan hari Kamis, selama dengan tingkatan level.

Tabel Kategori Level dan Target Pembelajaran MI Nurul Karim Karanganyar

\begin{tabular}{|c|c|c|c|c|}
\hline LEVEL & & KATEGORI & TARGET & CARA MENGAJAR \\
\hline $\begin{array}{l}\text { Tamhidi } \\
\text { (Kelas 1) }\end{array}$ & - & $\begin{array}{lr}\text { Belum } & \text { kenal } \\
\text { huruf } & \\
\text { Masih terbata bata } \\
\text { Belum kenal } \\
\text { tanda baca }\end{array}$ & $\begin{array}{l}\text { - Selesai karimah dasar dan } \\
\text { bisa membaca Al-Quran } \\
\text { terbata bata. } \\
\text { - Selesai Talqin Juz } 30 \\
\text { sebanyak } 25 \text { x dalam } 1 \text { tahun } \\
\text { - Hafal setengah Juz } 30 \text { An } \\
\text { Nas- Al Fajr dengan lancar/ } \\
\text { mutqin }\end{array}$ & $\begin{array}{l}\text { - Materi disampaikan } \\
\text { secara klasikal (per } \\
\text { halaqoh) } \\
\text { - Mentalqin ayat Secara } \\
\text { bersama sama sebanyak } \\
\text { 40x. (ayat yang akan di } \\
\text { hafal per hari H) } \\
\text { - Menerima setoran } \\
\text { bacaan karimah/ qiro'ah } \\
\text { dan hafalan dari yang } \\
\text { ditalqikan. }\end{array}$ \\
\hline $\begin{array}{l}\text { Talaqqi } \\
\text { (Kelas 2) }\end{array}$ & - & $\begin{array}{lr}\text { Sudah kenal huruf } \\
\text { namun } & \text { belum } \\
\text { lancar } & \text { dalam } \\
\text { membaca } & \end{array}$ & $\begin{array}{ll}\text { - } & \text { Lancar membaca juz } 29 \text { sd } \\
& 28 \\
\text { - } & \text { Selesai talqin juzz } 29 \text { sd } 28 \\
\text { - } & \text { Hafal 1 juz, yakni Juz } \\
& \text { 30\&29 ( Al-Ghasyiyah - Al } \\
& \text { Muzzammil) }\end{array}$ & $\begin{array}{l}\text { - Mentalqin ayat Secara } \\
\text { bersama sama sebanyak } \\
\text { 40x. } \\
\text { - Menerangkan materi } \\
\text { dan tanda baca secara } \\
\text { singkat } \\
\text { - Menguji bacaan dan } \\
\text { hafalan dari yang } \\
\text { ditalqikan }\end{array}$ \\
\hline $\begin{array}{l}\text { Tahfidz Awal } \\
\text { Kelas } 3\end{array}$ & - & $\begin{array}{l}\text { Tidak terjadi } \\
\text { kesalahan Jaly } \\
\text { mandiri dalam } \\
\text { menghafal }\end{array}$ & $\begin{array}{ll}\text { - } & \text { selesai talqin Juz } 27 \text { sd } 26 \\
\text { - } & \text { hafal } 1 \text { juz,yakni juz } 29 \text { \& } 28 \\
& \text { (Al Jin- As Shaf }\end{array}$ & $\begin{array}{l}30 \text { menit awal } \\
\text { mentalqinkan } 3 \text { baris } \\
\text { Mushaf dengan } \\
\text { 30x pengulangan } \\
\text { mentalqinkan Juz } 27 \text { sd } \\
26\end{array}$ \\
\hline $\begin{array}{l}\text { Tahfidz akhir } \\
\text { Kelas ( } 4 \text { dan } 5 \text { ) }\end{array}$ & - & $\begin{array}{l}\text { Tidak terjadi } \\
\text { kesalahan jaly dan } \\
\text { khofy } \\
\text { Mendiri dalam } \\
\text { menghafal }\end{array}$ & $\begin{array}{l}\text { - Hafal 2,5 juz, yakni Juz 28, } \\
27 \text { \& } 26 \text { (Al Mumtahanah - } \\
\text { Al Ahqaf) } \\
\text { - mampu mentasmi' } 3 \text { juz } \\
(30,29,28)\end{array}$ & - Setoran dan Muraja'ah \\
\hline $\begin{array}{l}\text { Tahfidz Niha'i } \\
\text { Kelas } 6 \text { yang } \\
\text { dinyatakan lulus } \\
\text { dari kelas tahfidz } \\
\text { akhir }\end{array}$ & - & $\begin{array}{l}\text { Tidak terjadi } \\
\text { kesalahan jaly dan } \\
\text { khofy } \\
\text { Mendiri dalam } \\
\text { muroja'ah }\end{array}$ & $\begin{array}{l}\text { - Mampu tasmi' } 5 \text { juz }(30,29, \\
\text { 28, 27, 26) dengan lancar }\end{array}$ & $\begin{array}{l}\text { Muroja'ah semua hafalan } \\
\text { untuk persiapan tasmi' }\end{array}$ \\
\hline
\end{tabular}

Evaluasi pembelajaran al-Qur'an di MI Nurul Karim dilakukan dengan tiga model yaitu ujian kelas, ujian juziyyah, dan ujian juara umum tahfidz sekolah. Ujian kelas dilaksanakan oleh musyrif/ ah masing-masing dan waktu diserahkan kepada masing masing musyrif/ah, materi ujian disusaikan dengan tingkatan level atau kelas. Pada level tamhidy ujian setiap selesai menghafal 1 halaman, level talaqqi ujian setiap selesai menghafal 1 lembar, level tahfidz awal ujian setiap selesai 
setoran 2 lembar, level tahfidz akhir ujian dilaksanakan setiap selesai setoran $1 / 4$ juz dan level niha'I ujian dilaksanakan bagi murid yang sudah siap ujian 5juz. Evaluasi kedua yaitu evaluasi juziyyah, ujian 1 juz penuh yang dilaksanakan oleh mas'ul tahfidz, siswa boleh melanjutkan hafalan juz selanjutnya setelah dinyatakan lulus juziyyah dari penanggung jawab tahfidz. Evaluasi terakhir yaitu ujian juara umum terbaik tahfidz sekolah dalam rangka mencari peserta terbaik sekolah.

Faktor Pendukung dan Penghambat Implementasi Pembelajaran Al-Qur'an di SDIT Nur Hidayah

Faktor pendukung yang dapat mendorong terlaksananya pembelajaran al-Qur'an di SDIT Nur Hidayah dengan baik antara lain: 1) Memiliki SDM yang sudah tersertifikat dan adanya updgrading guru seperti kordinasi setiap pekan dan workshop guru, terkhusus guru tahfidz. Kualitas dan kompetansi guru sangat berpengaruh terhadap kualitas dan kesuksesan pembelajaran. Salah satu langkah konkrit untuk menjaga dan mengingkatkan kuliatas dan kompetensi guru adalah dengan adanya pelatihan-pelatihan atau workshop, pembekalan serta pemberdayaan guru. 2) Menggunakan buku ajar dengan masing-masing tingk atan, yang terbagi menjadi beberapa jilid dengan adanya alat bantu baca atau alat peraga. Fungsi dari alat peraga adalah mempermudah penyampaian materi, dapat menimbulkan minat dan semangat dari peserta didik, sebagai instrument pembelajaran yang efektif dan efisien. 3) Memiliki nada atau senandung khas tersendiri, sehingga anak lebih mudah mengingat dan melafadzkan al-Qur'an. 4) Memiliki kelas I'dad terkhusus untuk kelas 1 SD.

Selain itu ada beberapa faktor penghambat dalam implementasi pembelajaran al-Qur'an di SDIT Nur Hidayah yaitu: masih terdapat anak yang belum lancar membaca al-Qur'an terutama kelas awal dan siswa yang baru terdaftar di SDIT Nur Hidayah, masih adanya peserta didik yang kurang memperhatikan secara maksimal dalam proses pembelajaran dan kurangnya bimbingan keluarga dalam suport terhadap peserta didik. Dalam kegiatan pembelajaran, siswa selalu mendapat sorotan yang utama. Guru harus memperhitungkan siapa siswa atau peserta didiknya yang dihadapi. Hal yang harus diperhatikan adalah tingkat intelektual dan latar belakang pendidikan para peserta, umur dan lingkungan sosial serta budayanya. Selain itu juga lingkungan keluarga yang dapat berpengaruh terhadap keberhasilan belajar anak antara lain: hubungan antara anggota keluarga, pola asuh keluarga dalam mendidik anak, suasa rumah tingkat ekonomi dan latar belakang budaya.

\section{Faktor Pendukung dan Penghambat Implementasi Pembelajaran Al-Qur'an di MI Nurul Karim}

Faktor pendukung dalam implementasi pembelajaran al-Qur'an di MI Nurul Karim yaitu: 1) Standarisasi pendidik yang mumpuni terkhusus, guru al-Qur'an. Ada beberapa kriteria yang harus dipenuhi oleh setiap guru tahfidz berdasarkan level atau tingkatan yang diampunya, yaitu: a) guru tamhidi (Kelas 1 \& 2) haruas memahami ilmu tajwid dasar, memiliki hafalan minimal 3 juz dan sudah menyetorkan hafalan kepada Muhafidz, b) guru talaqqi: memahami ilmu tajwid dasar, memiliki hafalan minimal 5 juz dan sudah menyetorkan hafalan kepada Muhafidz, c) guru tahfidz: memahami Ilmu Tajwid, memiliki hafalan 5 Juz dan sudah menyetorkan hafalan kepada Muhafidz. Pengetahuan 
seorang guru, pengalaman pembelajaran dan kompetensinya merupakan faktor penting dalam implementasi pembelajaran. Seorang guru harus dapat membuat penilaian yang rasional tentang kemampuan-kemampuan sendiri dan harus berusaha menggunakan metodemetode yang memungkinkan tercapainya tujuan pembelajaran. 2) Adanya inovasi dan strategi dalam penyampain pembelajaran, sehingga membantu anak untuk menyerap materi dengan baik, 3) Buku pegangan siswa yang mudah untuk di pahami, 4) Adanya kelas I'dad untuk kelas bawah atau pemula. Salah satu faktor yang dapat mempengaruhi keberhasilan guru dalam proses pembelajaran adalah pemilihan strategi dan metode yang tepat sesuai dengan pelajaran yang akan disampaikan. ${ }^{10}$

Faktor penghambat yang ditemukan yaitu 1) Masih ditemui beberapa siswa yang belum mahir membaca al-Qur'an. Kurangnya kemampuan membaca al-

10 Abdul Majid, Strategi Pembelajaran, (Bandung: PT Remaja Rosdakarya, 2013) h. 10
Qur'an dengan baik dan benar akan menimbulkan dua beban yang dirasakan oleh peserta didik yaitu beban membaca dan beban menghafal. Sehingga diperlukannya pendampingan yang lebih dan latihan secara terus menerus juga sering mendengarkan murotal bacaan para penghafal al-Qur'an. 2) Masih ditemui beberapa anak kurang konsentrasi dan perhatian dalam proses pembelajaran alqur'an dan ketika muroja'ah al-Qur'an. Apabila seorang anak tidak memeliki minata terhadap apa yang sedang dipelajari maka anak tidak akan akan bersemangat bahkan tidak mempunyai keinginan untuk belajar. Selain itu, perlu juga adanya motivasi atau dorongan baik dari diri sendiri ataupun orang tua dan orang-orang terdekatnya.

Terdapat perbedaan implementasi pembelajaran al-Qur'an dengan metode littaqwa di SDIT Nur Hidayah Surakarta dan metode karimah di MI Nurul Karim Karanganyar. Perbedaan tersebut dapat dilihat pada tabel berikut:

Tabel Perbedaan Implementasi Pembelajaran Al-Quran Metode Littaqwa dan Karimah

\begin{tabular}{|c|c|c|c|}
\hline No & Perbedaan & SDIT Nur Hidayah & MI Nurul Karim \\
\hline 1. & Target & 2 juz ( juz 29 dan 30) & 5 juz (juz 26, 27, 28, 29, dan 30) \\
\hline 2. & Sistem & Halaqoh sesuai kemampuan & Klasikal per kelas \\
\hline 3. & Model & $\begin{array}{l}\text { Tiga model yaitu klasikal bersama } \\
\text { guru, klasikal mandiri dan klasikal } \\
\text { satu-satu. }\end{array}$ & $\begin{array}{l}\text { Lima model yaitu talqin, tiqrar, } \\
\text { tahqiq dan tabyin }\end{array}$ \\
\hline 4. & Waktu & Setiap hari & Hari Senin- Kamis \\
\hline 5. & Materi & 5 jilid (jilid 1-5) & 1 buku karimah \\
\hline 6. & Evaluasi & $\begin{array}{l}2 \text { tahap yaitu evaluasi harian dan } \\
\text { evaluasi kenaikan jilid }\end{array}$ & $\begin{array}{l}3 \text { tahap yaitu ujian kelas, juziyyahdan } \\
\text { ujian juara umum terbaik tahfidz } \\
\text { sekolah. }\end{array}$ \\
\hline
\end{tabular}

\section{PENUTUP}

Implementasi pembelajaran alQur'an di SDIT Nur Hidayah. Target utama pembelajaran adalah pemahaman tentang ran kaidah ilmu tajwid dengan target hafalan minimal 2 juz, pembelajaran dengan metode littaqwa menggunakan 5 buku yang terdiri dari buku jilid I'dad, jilid 1, jilid 2, jilid 3, dan jilid 4 (Tajwid, Gharib) dengan menerapkan tiga model pembelajaran yaitu klasikal bersama guru, klasikal mandiri dan klasikal satu-satu. Evaluasi dilakukan setiap akhir pertemuan dengan membaca tamrinat (latihan) yang ada pada akhir setiap materi dan evaluasi kenaikan jilid 
dilakukan jika anak benar-benar sudah menguasai semua materinya, lancar dan tidak salah dalam membacanya, termasuk hafal semua atau sebagian hadits-hadits pilihannya. Pengujian kenaikan tingkat/ jilid dilakukan dengan membaca acak setiap halaman tamrinaat (latihan) dari materi awal sampai materi akhir di setiap jilid yang diuji. Target utama pembelajaran al-Qur'an di MI Nurul Karim yaitu hafalan yang dimiliki oleh lulusannya \pm 5 juz. Pembelajaran dengan metode karimah yang diterapkan di MI Nurul Karim mempunyai empat prinsip pengajaran yaitu talqin, tikrar, tahqiq dan tabyin (menjelaskan secara singkat kesalahan pada saat terjadi kesalahan tajwid), peserta didik dibagi menjadi 4 level yaitu kelas tamhidi, kelas talaqqi, kelas tahfidz awal, dan kelas tahfidz tsany. Evaluasi pembelajaran dilakukan dengan 3 tahap yaitu ujian kelas, juziyyah dan puncaknya adalah ujian juara umum terbaik tahfidz sekolah. Faktor pendukung dan penghambat implementasi pembelajaran al-Qur'an Faktor pendukung dalam implementasi pembelajaran al-Qur'an di SDIT Nur Hidayah adalah SDM yang sudah tersertifikat dan adanya updgrading guru seperti kordinasi pekanan dan menghadirkan workshop guru, terkhusus guru tahfidz, menggunakan alat bantu baca dengan alat peraga, menggunakan buku ajar dengan masing-masing tingkatan, yang terbagi menjadi beberapa jilid, memiliki kelas I'dad terkhusus untuk kelas 1 SD, memiliki nada atau senandung khas tersendiri. Sedangkan faktor penghambat yang ditemui adalah masih terdapat peserta didik yang belum lancar membaca al-Qur'an terutama kelas awal, kurangnya bimbingan dan support dari keluarga terhadap anak, dan proses pembelajaran masih terdapat anak yang tidak memerhatikan secara maksimal. Di MI Nurul Karim faktor pendukungnya antara lain adanya inovasi dan strategi dalam penyampain pembelajaran sehingga membantu anakuntuk menyerap materi dengan baik, standarsasi pendidik yang mumpuni terkhusus guru al-Qur'an, buku pegangan siswa yang mudah untuk di pahami, dan adanya kelas I'dad untuk kelas bawah atau pemula. Sedangkan faktor penghambat yang ditemui yaitu masih ditemui yaitu beberapa siswa yang belum mahir memebaca al-Qur'an dan masih ada beberapa anak yang kurang konsentrasi dan perhatian dalam proses pembelajaran al-qur'an dan ketika murojaah al-Qur'an.

\section{DAFTAR PUSTAKA}

Al-Hafidz, Ahmad Y., Arham bin. (2013). Agar Sehafal Al-Fatihah. Bogor: CV Hilal Media Group.

AS, Salafuddin. (2018). Ngaji Metal Metode Talqin. Jakarta: Wali Pustaka.

Derajar, Zakiyah. (1996). Ilmu Pendidikan Islam. Jakarta: Bumi Aksara.

Kaelan. (2012). Metode Penelitian Kualitatif Interdisipliner. Yogyakarta: Paradigma.

Majid, Abdul. (2013). Strategi Pembelajaran. Bandung: PT Remaja Rosdakarya.

Muthoifin, Ari Anshori dan Suryono. (2016) Metode Pembelajaran Ta fi- Al-Qur'an Di Madrasah Aliyah Ta-fir Nurul Iman Karanganyar Dan Madrasah Aliyah Al-Kahfi Surakarta. Profetika Jurnal Studi Islam, Vol. 17, No 02, Desember 2016.

Mengungkap Isi Pendidikan Islam Perspektif Al-Qur'an Surat Al-Ashr Ayat 1-3, Proseding the 7th University Research Colloqium 2018 STIKES PKU Muhammadiyah Surakarta, 2018. 
Implementasi Pembelajaran Al-Qur'an...(Sugiyanto et al.)

Nazir, Moh. (2013). Metode Penelitian. Bogor: Ghalia Indonesia.

Shobron, Sudarsono dkk. (2016). Pedoman Penulisan Tesis. Surakarta: Program Pascasarjana Universitas Muhammadiyah Surakarta. 